\title{
Genes related to high temperature tolerance during maize seed germination
}

\author{
S.M.F. Dutra', E.V.R. Von Pinho' ${ }^{2}$ H.O. Santos ${ }^{2}$, A.C. Lima², R.G. Von Pinho² \\ and M.L.M. Carvalho ${ }^{2}$ \\ ${ }^{1}$ Departamento de Produção Vegetal, Universidade Estadual Paulista, \\ Jaboticabal, SP, Brasil \\ ${ }^{2}$ Departamento de Agricultura, Universidade Federal de Lavras, Lavras, MG, Brasil \\ Corresponding author: S.M.F. Dutra \\ E-mail: sophiamfd@gmail.com \\ Genet. Mol. Res. 14 (4): 18047-18058 (2015) \\ Received June 12, 2015 \\ Accepted September 23, 2015 \\ Published December 22, 2015 \\ DOI http://dx.doi.org/10.4238/2015.December.22.31
}

ABSTRACT. The identification of genes related to heat tolerance is fundamental for the development of high-quality seeds that are tolerant to heat stress condition. The objective of this study was to evaluate maize lineages and the gene expression involved in high temperature tolerance during germination using physiological tests, proteomics, and transcriptome analysis. Seeds from six maize lineages (30, 44, 54, 63,64 , and 91) with different levels of tolerance to high temperatures were used. Lineages 54 and 91 were observed to be more tolerant to high temperature conditions. The highest expression of $\alpha$-amylase was observed in maize seeds from lineages 30 and 91 that were subjected to controlled deterioration. The highest expression of $\alpha$-amylase was observed in maize seeds from lineages 30 and 91 that were subjected to controlled deterioration; with the controlled deterioration, the highest level of gene expression did not occur in the most tolerant materials; the association of lower expression of genes involved in heat-resistant protein systems was observed in seeds from lineage 44, which were more susceptible to high temperatures, and the highest gene expression 
of LEA D-34, ZmAN13, and AOX-1 was observed in seeds from lineage 64 when submitted to controlled deterioration.

Key words: RT-qPCR; Proteomics; Abiotic stress

\section{INTRODUCTION}

The stress caused by high temperatures usually occurs over a period of time sufficient to cause irreversible damage to plant growth and development. Heat tolerance is generally defined as the ability of a plant to grow and produce at high temperatures (Peet and Willits, 1998).

Temperature is one of the most important factors in seed germination (Nerson, 2007), and can change the percentage, speed, and uniformity of germination (Marcos Filho, 2005). Cargnin et al. (2006) worked with seeds from eight progenitor and eight segregating populations (generation F3) of wheat and concluded that high temperature during seed germination leads to a reduction in the dry weight of seedlings and in the efficiency of endosperm use. Under high temperature conditions, the production of reactive oxygen species (ROS) is high, which can damage DNA, proteins, and lipids (Miller et al., 2008). Therefore, plant mitochondria have a proactive defense system of power dissipation, which significantly decreases the rate of ROS production in the mitochondria by the electron transport chain, thus from the maintenance of low level of reduction of ubiquinone (Keunen et al., 2013). In this system, the alternative oxidase (AOX) operates.

According to Allakhverdiev et al. (2008), heat tolerance in plant cells may be provided by the following factors: an increase in the expression of heat tolerance proteins, an increase in antioxidant activity, an increase in the unsaturation of the lipid membrane, expression and translation of genes related to tolerance, and thermal stability of proteins.

Immediately after exposure to high temperatures, changes occur at the molecular level, including altered expression of genes and changes in transcript accumulation, which increases the synthesis of stress-related proteins, such as tolerance strategy (Iba, 2002). High temperatures induce the accumulation of the LEA proteins embryogenesis accumulated. The mRNA of these proteins appears in embryonic tissues and decreases gradually after seed imbibition (Baker et al., 1988; Galau et al., 1991).

According to Boucher et al. (2010), an important feature of survival in the dry state is the ability to protect membranes during the transition phase in order to prevent loss of integrity. This role has been attributed to dehydrins, heatshock proteins, and LEA proteins. In maize, however, few studies have investigated the transcription, translation, and activation of these enzymes during germination under high temperatures. Other genes appear to be involved in achieving tolerance to high temperatures. Gene expression now can be studied due to advances in biotechnology. The study of these genes is only possible in protein level or cellular transcripts.

Maximizing the sensitivity of quantification methods has led to the development of increasingly complex techniques, including quantitative real-time PCR ( $\mathrm{PPCR}$ ), which has been used in the medical field for a long time, and has been used as a tool in studies investigating gene expression and quantification of specific sequences in plants (Gachon and Saindrenan, 2004). Thus, using the technique of real-time PCR, it is possible to identify genes that may be involved in the mechanism for achieving tolerance to high temperatures.

Xuan (2011) described the functional characterization of ZmAN13 from the ZnFAN1 family in maize, which is induced in response to abiotic stresses. Proteins of connecting element that 
respond to dehydration (DREBs) play vital regulatory functions in the response to abiotic stress in plants. ZmDBP2 gene transcription was found to be highly induced by drought and moderately induced by salt and exogenous abscisic acid (Wang et al., 2011).

Therefore, the aim of this study was to evaluate maize lineages and gene expression involved in tolerance to high temperatures during germination using physiological tests, proteomics, and transcriptome analysis.

\section{MATERIAL AND METHODS}

This research was conducted in the experimental area and in the Central Seed Laboratory of the Agriculture Department at the Federal University of Lavras (UFLA), in Lavras, MG. Seeds from six different maize lineages $(30,44,54,63,64$, and 90$)$ that have different levels of tolerance to high temperatures were used. For the physiological assessment of maize seeds in relation to different temperatures during germination, the following tests were performed:

Water content was determined by the oven method at $105^{\circ} \mathrm{C}$ for $24 \mathrm{~h}$ (Brazil, 2009). Results are expressed as mean percentage (wet basis). A germination test was performed at five different temperatures $\left(25^{\circ}, 30^{\circ}, 35^{\circ}, 40^{\circ}\right.$, and $\left.45^{\circ} \mathrm{C}\right)$, and for each temperature the test was conducted with four replications of 50 seeds. The seeds were sown between paper moistened with distilled water at a ratio of 2.5-times the weight of the dry paper. The rolls were stored in plastic bags and kept in B.O.D chambers each regulated at one of the five temperatures. Normal seedling evaluations were performed 4, 7, and 14 days after planting. Normal seedlings were considered to have a standard primary root length of $0.5 \mathrm{~cm}$. Results are expressed as mean percentage.

After the germination test was performed at different temperatures, $35^{\circ} \mathrm{C}$ was able to distinguish between the six lineages in terms of tolerance to high temperature at the first germination count. Based on these results, a temperature $35^{\circ} \mathrm{C}$ was used for subsequent tests and analyzes.

Physiological assessment of maize seeds submitted to a controlled deterioration test was performed using the following tests: Controlled deterioration involved increasing the water content of seeds to $25 \%$. The predetermined water content is reached by adding an amount of water to the seed as calculated by the formula:

$$
W 2=100-A / 100-B \times W 1
$$

where $A$ is the initial water content of seeds (based on wet weight); $B$ is the amount of water required; W1 is the initial seed weight $(\mathrm{g})$; W2 is the final seed weight $(\mathrm{g})$; and $\mathrm{W} 2$ - W1 is the water to be added (Wang et al., 1991; Hampton et al., 1992). Next, the seeds were packed in aluminum, heat sealed, and maintained for $24 \mathrm{~h}$ at $10^{\circ} \mathrm{C}$ to standardize water content. The seeds were aged at $42^{\circ} \mathrm{C}$ for $48 \mathrm{~h}$ in a germination chamber (B.O.D.-Marconi). After this period, the seeds were maintained at room temperature until the water content reached close to $13 \%$, and seeds were later submitted to a germination test at $35^{\circ} \mathrm{C}$. Normal seedling evaluations were performed 4 and 7 days after planting. A primary root length of $0.5 \mathrm{~cm}$ was adopted as a standard of normal seedlings.

The length and dry mass of shoots and roots were determined in seeds that were and were not submitted to controlled deterioration. The test was conducted with four replicates of 15 seeds, and the seeds were sown between paper moistened with distilled water at a ratio of 2.5-times the weight of the dry paper. The rolls were stored in plastic bags and kept in a B.O.D chamber set at 
$35^{\circ} \mathrm{C}\left(+\right.$ or $\left.-1^{\circ} \mathrm{C}\right)$ for 7 days. Lengths of the shoot and the root systems were performed on a single assessment 7 days after sowing. The dry mass of the shoot and the root system was determined separately. The tissues were separated from the seeds, packed in paper bags, and placed in the oven at $60^{\circ} \mathrm{C}$ until weight stabilization.

For proteomic analyses, seeds that were and were not submitted to controlled deterioration were used. The following enzymes and proteins were extracted and their levels assessed:

Heat resistant protein was assessed using seed embryos. The extraction was performed according to the method described by Blackman et al. (1991) and the calculation was performed according to the method described by Alfenas (2006). Enzyme $\alpha$-amylase: the seeds were imbibed for a period of $72 \mathrm{~h}$ at $25^{\circ} \mathrm{C}$. After this period, the embryonic axes and scutella were discarded and the remaining endosperms were used for extraction. The calculations were performed according to the method described by Alfenas (2006). Enzymes catalase (CAT), esterase (EST), and superoxide dismutase (SOD): whole seeds were used for extraction. Calculations were performed in accordance with the method described by Alfenas (2006). Transcriptomic analysis in relation to heat tolerance was performed by the qRT-PCR technique in four steps: RNA extraction and purification, reverse transcription for cDNA synthesis, RT-PCR, and analysis of results. For RNA extraction, seeds from six lineages that were and were not submitted to controlled deterioration were used.

\section{Design of primers}

For the analysis of gene expression by qRT-PCR, genes were selected based on literature review because of the importance in the study of plant tolerance to high temperatures. The primers were designed with help of the Primer Express 3.0 software (Applied Biosystems) following the search for gene sequences in http://www.ncbi.nlm.nih.gov site (Table 1). As controls endogenous genes UBI and DHA were used.

\begin{tabular}{|c|c|c|}
\hline Gene* $^{*}$ & Identification & Sequence $\left(5^{\prime}-3^{\prime}\right)$ \\
\hline ZmAN13 & Regulatory role in response to abiotic stress & $\begin{array}{l}\text { F: AGCTGTTGCCCAAGTCGAGTT } \\
\text { R: GCTGGGTCCGGCAACAT }\end{array}$ \\
\hline$A O X-1$ & Alternative route of breathing/antioxidant & $\begin{array}{l}\text { F: GCGAGGAGCAAACAGCAAA } \\
\text { R: GGCCACTAGTGCGGTCAACT }\end{array}$ \\
\hline$A O X-2$ & Alternative route of breathing/antioxidant & $\begin{array}{l}\text { F: CCAAGACGCTGATGGATAAGG } \\
\text { R: AGCCATACCGCCTCTGGAA }\end{array}$ \\
\hline$Z m D B P 2$ & Proteins of connecting element responsive to dehydration & $\begin{array}{l}\text { F: CAATACCAGCGCACACCAGAT } \\
\text { R: TCGTTATAAAAGGCTCGAGTGCTT }\end{array}$ \\
\hline LEAP (D-34) & Heat-resistant proteins & $\begin{array}{l}\text { F: CCGGCTCCACGCAGAAC } \\
\text { R: TATAGGCGTAGCCCTGCATGA }\end{array}$ \\
\hline LEAP & Heat-resistant proteins & $\begin{array}{l}\text { F: TGCAGCTCCTAGTGCTTGTAC } \\
\text { R: TGGAAGAGGACCTGGGATTG }\end{array}$ \\
\hline UBI & Endogenous control & F: AAGGCCAAGATCCAGGACAA \\
\hline$A D H$-DA & Endogenous control & $\begin{array}{l}\text { R: TTGCTTTCCAGCGAAGATGA } \\
\text { F: AGGACGCTGAGTTAAGACC }\end{array}$ \\
\hline
\end{tabular}

*LEAP $(\mathrm{D}-34)=$ late embryogenesis abundant protein D-34; LEAP = late embryogenesis abundant protein; UBI = ubiquitin; $A D H=$ alcohol dehydrogenase; $F=$ primer sequence forward; $R$ = primer sequence reverse.

The tests performed to assess the physiological quality were conducted in a completely randomized factorial $6 \times 5$ design, using six genotypes and five temperatures, with four replications; 
and a $6 \times 2$ design, using six genotypes and two conditions. The data were previously subjected to tests of residual normality and homoscedasticity of variance, and were submitted to variance analysis. Means were compared using the Scott and Knott test, at a $5 \%$ level of probability. Analyses were performed in the statistical program SISVAR ${ }^{\circledR}$ (Ferreira, 2000). Data from real-time PCR were analyzed using the 7500 SDS software program (Version 2.0.1) (Applied Biosystems).

\section{RESULTS}

\section{Physiological analysis of maize seeds under different germination temperatures}

Higher germination and vigor values were observed in seeds belonging to lineages 30 and 91 four days after the start of the test at $25^{\circ} \mathrm{C}$ (Table 2), and the lowest germination value was observed in seeds from lineage 44 . At $30^{\circ} \mathrm{C}$, there was no significant difference among the six lineages evaluated. At $35^{\circ} \mathrm{C}$, a lower germination value was observed in seeds belonging to lineage 44, while higher germination percentages values were observed in seeds belonging to lineage 91 , followed by those belonging to lineage 54 .

\begin{tabular}{|c|c|c|c|c|c|}
\hline \multirow[t]{2}{*}{ Lineages } & \multicolumn{5}{|c|}{ Temperature $\left({ }^{\circ} \mathrm{C}\right)$} \\
\hline & $25^{\circ} \mathrm{C}$ & $30^{\circ} \mathrm{C}$ & $35^{\circ} \mathrm{C}$ & $40^{\circ} \mathrm{C}$ & $45^{\circ} \mathrm{C}$ \\
\hline \multicolumn{6}{|l|}{4 days } \\
\hline 30 & $97^{\text {Aa }}$ & 99Аа & $76^{\mathrm{cb}}$ & $0^{A C}$ & $\mathrm{O}^{\mathrm{AC}}$ \\
\hline 44 & $83^{\mathrm{bb}}$ & $99^{\mathrm{Aa}}$ & $64^{\mathrm{Ec}}$ & $0^{\text {Ad }}$ & $\mathrm{O}^{\text {Ad }}$ \\
\hline 54 & $88^{\mathrm{cb}}$ & $100^{\mathrm{Aa}}$ & $82^{\mathrm{Bc}}$ & $0^{\text {Ad }}$ & $\mathrm{O}^{\text {Ad }}$ \\
\hline 63 & $90^{\mathrm{cb}}$ & $97^{\mathrm{Aa}}$ & $70^{\circ \mathrm{c}}$ & $0^{\text {Ad }}$ & $\mathrm{O}^{\text {Ad }}$ \\
\hline 64 & $93^{\text {в }}$ & $97^{\mathrm{Aa}}$ & $68^{D c}$ & $0^{\text {Ad }}$ & $O^{\text {Ad }}$ \\
\hline 91 & $98^{\mathrm{Aa}}$ & $100^{A a}$ & $99^{\text {Аa }}$ & $0^{A b}$ & $0^{A \mathrm{BD}}$ \\
\hline \multicolumn{6}{|l|}{7 days } \\
\hline 30 & $99^{\text {Aa }}$ & $99^{\mathrm{Aa}}$ & $99^{\mathrm{Aa}}$ & $90^{\mathrm{Ab}}$ & $\mathrm{O}^{\mathrm{AC}}$ \\
\hline 44 & $100^{\mathrm{Aa}}$ & $100^{\mathrm{Aa}}$ & $100^{\mathrm{Aa}}$ & $81^{\mathrm{Bb}}$ & $\mathrm{O}^{\mathrm{AC}}$ \\
\hline 54 & $100^{\mathrm{Aa}}$ & $100^{\mathrm{Aa}}$ & $99^{\mathrm{Aa}}$ & $94^{\mathrm{AB}}$ & $\mathrm{O}^{\mathrm{AC}}$ \\
\hline 63 & $99^{\mathrm{Aa}}$ & $98^{\mathrm{Aa}}$ & $98^{\text {Aa }}$ & $92^{\mathrm{Ab}}$ & $\mathrm{O}^{\mathrm{AC}}$ \\
\hline 64 & $99^{\mathrm{Aa}}$ & $98^{\mathrm{Aa}}$ & $98^{\mathrm{Aa}}$ & $92^{\mathrm{AB}}$ & $0^{A C}$ \\
\hline 91 & $100^{\mathrm{Aa}}$ & $100^{\mathrm{Aa}}$ & $100^{\mathrm{Aa}}$ & $96^{\mathrm{Aa}}$ & $\mathrm{O}^{\mathrm{Ab}}$ \\
\hline \multicolumn{6}{|l|}{14 days } \\
\hline 30 & $99^{\mathrm{Aa}}$ & $99^{\mathrm{Aa}}$ & $99^{\mathrm{Aa}}$ & $94^{\mathrm{cb}}$ & $\mathrm{O}^{\mathrm{AC}}$ \\
\hline 44 & $100^{\mathrm{Aa}}$ & $100^{\mathrm{Aa}}$ & $100^{\mathrm{Aa}}$ & $93^{\mathrm{cb}}$ & $\mathrm{O}^{\mathrm{AC}}$ \\
\hline 54 & $100^{\mathrm{Aa}}$ & $100^{\mathrm{Aa}}$ & $99^{\mathrm{Aa}}$ & $97^{\mathrm{Bb}}$ & $\mathrm{O}^{\mathrm{AC}}$ \\
\hline 63 & $99^{\mathrm{Aa}}$ & $98^{\mathrm{Aa}}$ & $98^{\text {АВ }}$ & $95^{\mathrm{cb}}$ & $1^{A c}$ \\
\hline 64 & $99^{\mathrm{Aa}}$ & $98^{\mathrm{Aa}}$ & $98^{\mathrm{Aa}}$ & $93^{\mathrm{cb}}$ & $1^{\mathrm{Ac}}$ \\
\hline 91 & $100^{\mathrm{Aa}}$ & $100^{\mathrm{Aa}}$ & $100^{\text {Aa }}$ & $99^{\text {Aa }}$ & $\mathrm{O}^{\mathrm{AB}}$ \\
\hline
\end{tabular}

Results followed by the same lowercase letter on the line and uppercase letter on the column do not differ at $5 \%$ probability as determined by the Scott-Knott test.

At temperatures of $40^{\circ}$ and $45^{\circ} \mathrm{C}$, no germination was observed in seeds from the six lineages. The highest values of germination were observed at a temperature of $30^{\circ} \mathrm{C}$. There were no significant differences between the tested lineages nor between the temperatures $25^{\circ}, 30^{\circ}$, and $35^{\circ} \mathrm{C}$ when assessed on day 7 (Table 2). At $40^{\circ} \mathrm{C}$, a lower germination value was observed in seeds from the lineage 44 . The other lineages did not differ with each other. At $45^{\circ} \mathrm{C}$, no seed germination was observed in the evaluated lineages. According to the results observed 14 days after sowing, there were no statistical differences in the germination of seeds from all lineages 
germinated at $25^{\circ}, 30^{\circ}, 35^{\circ}$, and $45^{\circ} \mathrm{C}$ (Table 2). At $40^{\circ} \mathrm{C}$, seeds belonging to lineage 91 had the greatest germination value, followed by those from lineage 54 .

\section{Physiological analysis of maize seeds submitted or not to the controlled deterioration test}

On the fourth assessment day, lower germination percentages values were observed in seeds submitted to deterioration. Under this condition, higher germination values were observed in seeds belonging to lineages 44 and 63, and the lowest value was observed in those from lineage 64 (Table 3). In the seeds not submitted to aging, lower germination was observed in seeds from lineage 44, and no significant difference was observed for the results from seeds of other lineages (Table 3).

Table 3. Percentage germination of seeds from six maize lineages submitted (SDC) and not submitted (NSDC) for a controlled deterioration test at 4 and 7 days after installation of the test.

\begin{tabular}{|c|c|c|}
\hline \multirow[t]{2}{*}{ Lineages } & \multicolumn{2}{|c|}{ Temperature $\left(35^{\circ} \mathrm{C}\right)$} \\
\hline & NSDC & SDC \\
\hline \multicolumn{3}{|l|}{4 days } \\
\hline 30 & $98^{\mathrm{Aa}}$ & $29^{\mathrm{Db}}$ \\
\hline 44 & $64^{\mathrm{Ba}}$ & $52^{\mathrm{Ab}}$ \\
\hline 54 & $100^{\mathrm{Aa}}$ & $36^{\mathrm{cb}}$ \\
\hline 63 & $99^{A a}$ & $54^{\mathrm{Ab}}$ \\
\hline 64 & $96^{\mathrm{Aa}}$ & $15^{\mathrm{Eb}}$ \\
\hline 91 & $99^{\mathrm{Aa}}$ & $48^{\mathrm{Bb}}$ \\
\hline \multicolumn{3}{|l|}{7 days } \\
\hline 30 & $99^{\mathrm{Aa}}$ & $83^{\mathrm{Bb}}$ \\
\hline 44 & $100^{A a}$ & $86^{\mathrm{Bb}}$ \\
\hline 54 & $99^{\mathrm{Aa}}$ & $83^{\mathrm{Bb}}$ \\
\hline 63 & $98^{\mathrm{Aa}}$ & $72^{\mathrm{cb}}$ \\
\hline 64 & $98^{\text {Aa }}$ & $23^{\mathrm{Db}}$ \\
\hline 91 & $100^{\mathrm{Aa}}$ & $95^{\mathrm{Aa}}$ \\
\hline
\end{tabular}

Results followed by the same lowercase letter on the line and uppercase letter on the column do not differ with each other at $5 \%$ probability by the Scott-Knott test.

On day 7 , there was no significant difference in seeds from the tested lineages that were not submitted to controlled deterioration. However, in seeds submitted to controlled deterioration, lower germination values were observed in those from lineage 64 and the highest value was observed in those from lineage 91 (Table 3).

In relation to the dry matter of shoots, higher values were observed in seedlings generated from seeds that had not undergone controlled deterioration. Under this condition, a greater amount of dry matter was observed in seedlings from seeds belonging to lineage 91 , followed by those from lineage 54. Higher dry matter values were observed in seedlings from seeds belonging to lineages 44 and 91 that had undergone deterioration (Table 4).

Concerning the dry matter of root systems (Table 4) in seedlings generated from seeds that had not undergone controlled deterioration, a high value was observed in those from lineage 91. For seeds submitted to controlled deterioration, higher dry matter values were observed for seedlings from lineages 44, 54, and 91.

Shoot length (Table 4) was high in seedlings from lineage 91, both from seeds submitted to controlled deterioration and in those not submitted to controlled deterioration. Lower shoot length values were observed in seedlings from lineage 64 when submitted to controlled deterioration. 
Table 4. Dry matter shoot (DMS), roots (DMR), length of shoot (LS), and length of root system (LRS) of seedlings from six maize lines derived from seeds submitted (SDC) and not submitted (NSDC) for a controlled deterioration test.

\begin{tabular}{|c|c|c|}
\hline Lineages & DMS & NSDC \\
\hline \multicolumn{3}{|l|}{ DMS } \\
\hline 30 & $0.89^{\mathrm{ca}}$ & $0.04^{\mathrm{b}}$ \\
\hline 44 & $1.07^{\mathrm{ca}}$ & $0.29^{A b}$ \\
\hline 54 & $1.76^{\mathrm{Ba}}$ & $0.08^{\mathrm{Bb}}$ \\
\hline 63 & $1.22^{\mathrm{ca}}$ & $0.04^{\mathrm{bb}}$ \\
\hline 64 & $1.11^{\mathrm{Ca}}$ & $0.01^{\mathrm{Bb}}$ \\
\hline 91 & $2.67^{\text {Аа }}$ & $0.36^{\mathrm{Ab}}$ \\
\hline \multicolumn{3}{|l|}{ DMR } \\
\hline 30 & $0.23^{\mathrm{ca}}$ & $0.06^{\mathrm{b}}$ \\
\hline 44 & $0.29^{\mathrm{ca}}$ & $0.39^{\mathrm{Aa}}$ \\
\hline 54 & $0.38^{\mathrm{ca}}$ & $0.26^{\mathrm{Aa}}$ \\
\hline 63 & $0.68^{\mathrm{Ba}}$ & $0.14^{\mathrm{bb}}$ \\
\hline 64 & $0.26^{\mathrm{ca}}$ & $0.01^{\mathrm{Bb}}$ \\
\hline 91 & $0.97^{\text {Aa }}$ & $0.34^{\mathrm{Ab}}$ \\
\hline \multicolumn{3}{|l|}{ LS } \\
\hline 30 & $10.41^{\mathrm{ca}}$ & $1.30^{c b}$ \\
\hline 44 & $17.08^{\text {ва }}$ & $4.12^{\mathrm{Bb}}$ \\
\hline 54 & $11.55^{\mathrm{ca}}$ & $3.10^{\mathrm{Bb}}$ \\
\hline 63 & $12.53^{\mathrm{ca}}$ & $0.78^{\mathrm{cb}}$ \\
\hline 64 & $13.48^{\mathrm{ca}}$ & $0.14^{\circ \mathrm{b}}$ \\
\hline 91 & $20.59^{\text {Aa }}$ & $7.25^{\mathrm{Ab}}$ \\
\hline \multicolumn{3}{|l|}{ LRS } \\
\hline 30 & $7.50^{\text {ва }}$ & $0,83^{\mathrm{cb}}$ \\
\hline 44 & $5.30^{\mathrm{ca}}$ & $4.50^{\mathrm{Aa}}$ \\
\hline 54 & $8.94^{\mathrm{Ba}}$ & $1.50^{\mathrm{Bb}}$ \\
\hline 63 & $8.55^{\text {ва }}$ & $0.61^{\mathrm{cb}}$ \\
\hline 64 & $9.35^{\text {ва }}$ & $0.45^{\mathrm{cb}}$ \\
\hline 91 & $20.59^{\text {Aa }}$ & $1.89^{\mathrm{Bb}}$ \\
\hline
\end{tabular}

Results followed by the same lowercase letter on the line and uppercase letter on the column do not differ with each other at $5 \%$ probability by the Scott-Knott test.

In seeds not submitted to controlled deterioration, the root system was a greater length in seedlings from lineage 91, and were shorter in seedlings from lineage 44 (Table 4). The root system was a greater length in seeds submitted to controlled deterioration in seedlings from lineage 44.

\section{Proteomic analysis}

There was higher expression of SOD in seeds from lineages 30 and 44 when submitted to controlled deterioration, which can be observed by the increased intensity of bands 1 and 2 (Figure 1A).

An increase in CAT expression was observed in seeds from lineages 30, 44, and 91 and reduced CAT expression was observed in seeds from lineages 54 and 63 . In seeds from lineages 30 and 44, this increased expression may be explained because of the higher expression of SOD under the same conditions (Figure 1B). By the enzyme esterase zymogram (EST) is inferred the expression of two loci (top and bottom of the figure) (Figure 1C). Relative to the first locus, increased EST expression was only observed in seeds from lineage 63 submitted to controlled deterioration. For the second locus, some isoforms were not observed in deteriorated seeds. With the exception of lineage 54, lower expression of this enzyme at the second locus was also observed in seeds belonging to the other lineages.

Considering both loci in seeds not submitted to controlled deterioration, greater EST 
expression was observed in seeds from lineage 64 and lower expression was observed in seeds from lineage 91.Expression of two additional isoforms ( $a$ and $b$ ) of a-amylase were observed in deteriorated seeds (Figure 1D) from lineage 91. Although these isoforms were both expressed, lower expression of $\alpha$-amylase was observed in deteriorated seeds from lineage 91 and higher expression was observed in seeds from lineage 30.

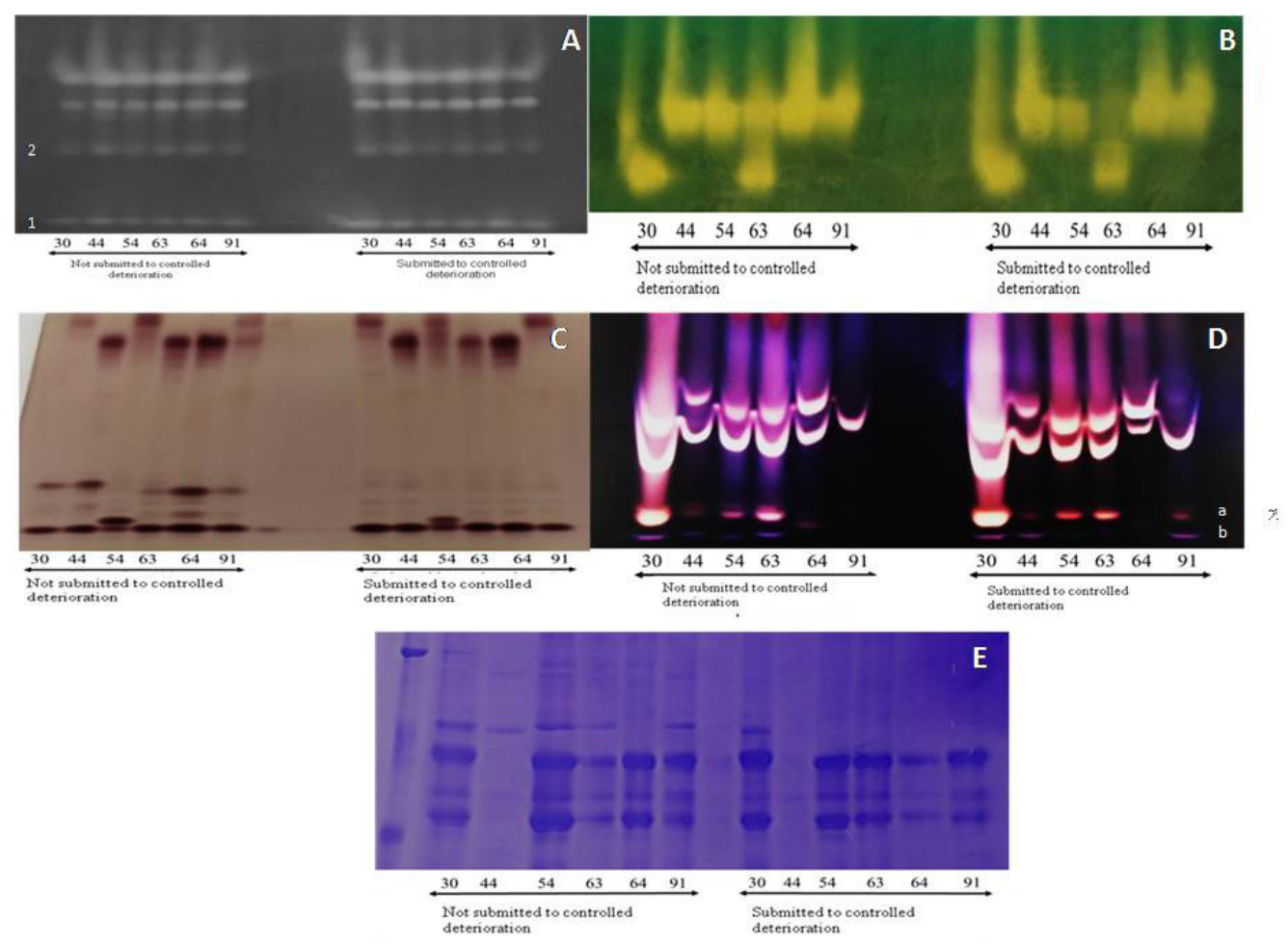

Figure 1. A. SOD enzyme activity in seeds from six maize lineages submitted or not to controlled deterioration. B. CAT enzyme activity in seeds from different maize lineages submitted or not to controlled deterioration. C. EST enzyme activity in seeds from different maize lineages submitted or not to controlled deterioration. D. $\alpha$-amylase enzyme activity in seeds from different maize lineages submitted or not to controlled deterioration. E. heat-resistant protein activity in seeds from different maize lineages submitted or not to controlled deterioration.

Regardless of whether seeds were submitted to controlled deterioration, those from lineage 44 were found to have lower expression of heat resistant proteins (Figure 1E). In seeds that were not deteriorated, greater expression of these proteins was observed in seeds from lineages 30 and 54 .

\section{Transcriptomic analysis}

Gene expression of LEA D-34 (Figure 2A) was higher in seeds submitted to controlled deterioration, and the highest expression was observed in seeds from lineage 64 . Both in seeds not deteriorated as in deteriorated seeds the lowest gene expression LEA D-34 was observed in seeds of the lineage 44 , classified as low tolerance to temperature of $40^{\circ} \mathrm{C}$ during the germination process. 


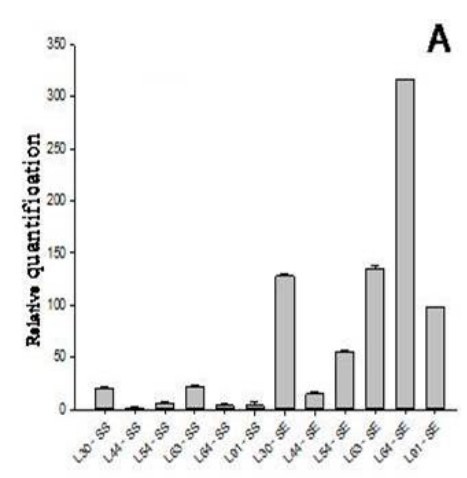

A

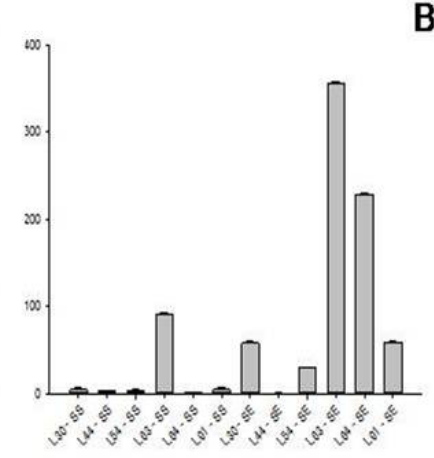

B

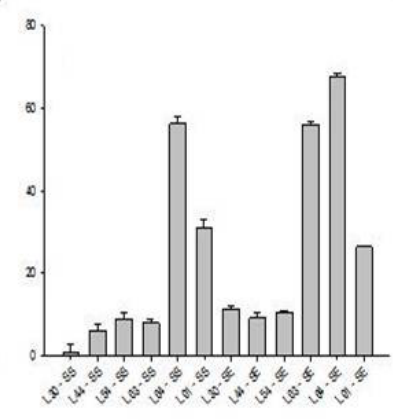

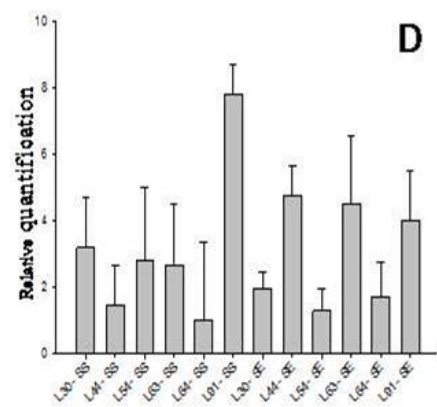
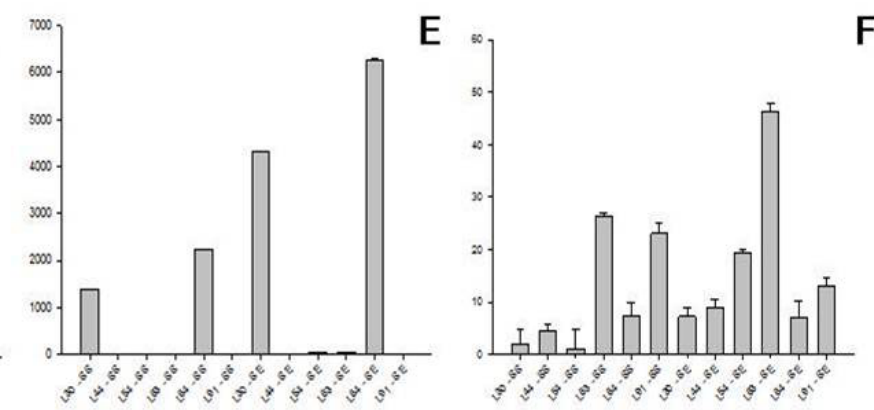

Figure 2. A. Gene expression. B. LEA D-34. C. LEA. D. ZmAN13. E. ZmDBP. F. AOX-1. G. AOX-2 in relation to seeds from six lineages that were submitted (SE) and not submitted (SS) to controlled deterioration.

Higher LEA expression was observed in seeds submitted to controlled deterioration, except in those from lineage 44 (Figure 2B). In all seeds regardless of the germination status, higher gene expression was observed in lineage 63. As shown in Figure 2C, higher ZmAN13 expression was observed in seeds from lineage 64 regardless of whether they were submitted to deterioration. The relative expression of $\mathrm{ZmDBP} 2$ is shown in Figure 2D. Gene expression varied depending on both the lineage and the deterioration status of the seeds. In seeds not submitted to controlled deterioration, higher expression of this gene was observed in lineage 91. Greater expression was observed in deteriorated seeds from lineage 44. AOX-1 expression was only observed in seeds from lineages 30 and 64 (Figure 2E), regardless of whether they had been submitted to deterioration. The highest expression of AOX-2 (Figure 2F) was observed in seeds from lineage 63, regardless of the state of deterioration.

The reliability of these results was confirmed through the use of an endogenous control gene, which was expressed at the same level regardless of the treatment used. In this study, the endogenous genes used were ubiquitin and alcohol dehydrogenase (ADH).

\section{DISCUSSION}

\section{Physiological analysis of maize seeds under different germination temperatures}

Higher values of germination were observed at $30^{\circ} \mathrm{C}$, which is recommended for use 
in maize seed germination tests since this temperature is expected to increase the expression of enzymes that favor germination. However, under field conditions in some regions where this crop is cultivated, the soil temperature can exceed $30^{\circ} \mathrm{C}$ during the germination process, which compromises the establishment of plants in the field.

Temperature is considered to be the most influential factor on the speed and percentage of seed germination and seedling emergence. A temperature range exists for all species in which the highest levels of germination and emergence occur, depending on the availability of an adequate moisture supply, and the presence of minimal adverse factors (Delouche, 2004). The ability of a seed to germinate under broad conditions is defined as the manifestation of its vigor, and is dependent, among other factors, on the environmental conditions found at the site where it was sown (De Simoni et al., 2011). Silva-Neta et al. (2014) performed a physiological assessment and ranked seeds from six maize lines $(44,54,57,63,64$, and 91$)$ according to their tolerance to low temperature germination. Lines 44,54 , and 57 were ranked as more susceptible, and lines 63,64 , and 91 were ranked as more tolerant to low temperatures for germination. Sbrussi et al. (2014) observed that from $35^{\circ} \mathrm{C}$ upwards a sharp and significant decline in the germination percentage of the six lots of maize seeds was observed, whereas no germination occurred at the maximum temperature of $45^{\circ} \mathrm{C}$.

High temperatures can also alter the composition and function of the lipid bilayer, which causes an increase in membrane fluidity, leading to disintegration of the lipid bilayer (Allakhverdiev et al., 2008). Furthermore, high temperatures may trigger the denaturation of enzymes and the expression of these enzymes may be reduced under these conditions.

\section{Physiological analysis of maize seeds in response to deterioration state}

Basavarajappa et al. (1991) found that accelerated aging of maize seeds led to a loss of membrane integrity. Free radicals, which are produced as a result of lipid peroxidation in aging, react with the lipids in cell membranes, leading to the destruction of cell membrane structure and of the seed reserves, resulting in reduced seed quality.

\section{Proteomic analysis}

SOD is the first enzyme involved in the antioxidant defense process, which acts to mitigate the action of SOD, catalyzing its conversion to hydrogen peroxide. When studying tolerance to low temperature during germination of seeds from six maize lines $(44,54,57,63,64$, and 91) Silva-Neta et al. (2014) found that there was a change in SOD expression in seeds from strain 63 , which are tolerant to low temperatures, following seed imbibition for $24 \mathrm{~h}$ at $25^{\circ} \mathrm{C}$, and that in most strains SOD expression was highest in seeds imbibed for $48 \mathrm{~h}$ at $25^{\circ} \mathrm{C}$. Abreu et al. (2014) studied tolerance to drought in seeds from five maize lineages $(44,54,63,64$, and 91$)$ and observed high SOD activity in hydric potential control (OMPa). As this was reducing hydric potential, a reduction in band intensity was observed for lineages 63,54 , and 64 , which did not occur in the lineages 91 and 44 . Higher vigor of seeds from lineages 91 and 44 was observed under conditions of hydric restriction. In these seeds, there was higher expression of enzymes involved in the antioxidant system. In plants under hydric stress, increased activity of this enzyme was found to be related to increased tolerance to drought (Zhu, 2002). SOD leads to the formation of hydrogen peroxide and then a second enzyme, CAT, is expressed to protect the seeds, since it transforms hydrogen 
peroxide into oxygen and water (Taiz and Zeiger, 2004; Buchanan et al., 2005). EST is involved in the hydrolysis of esters and is directly linked to lipid metabolism, including that of the phospholipid membrane.

Padilha et al. (2001) evaluated EST expression in hybrid maize seeds submitted to the controlled deterioration test for different imbibition times and seed water content. Changes in the expression of this enzyme were observe with the disappearance of some isoforms.

According to Franco et al. (2002), $\alpha$-amylase promotes the hydrolysis of starch to provide the necessary carbohydrates for the developing embryo, thus allowing maize seed germination. Working with different maize seeds lineages, Andrade et al. (2013) found that the expression of heat resistant proteins, as detected by electrophoresis, occurred during the early stages of development (LL 3) in lineages tolerant to high drying temperatures, when compared to lineages that are not tolerant to high drying temperatures.

\section{Transcriptomic analysis}

The gene ZmAN13 belongs to the ZnFAN1 family. According to Jin et al. (2007) and Xuan (2011), genes in this family in maize are expressed in response to abiotic stresses, such as stress caused by temperature. Transcription of ZmDBP2 is activated by thermal tolerance to high temperatures and by salt stress. Overexpression of ZmDBP2 confers thermal tolerance to high temperatures in transgenic Arabidopsis plants (Wang et al., 2011). Conditions that cause oxidative stress, such as abiotic stresses, induce AOX activity suggesting that this enzyme may function to reduce the formation of ROS produced as a result of decreased or restricted respiratory activity (Moore et al., 2002).

In conclusion, these data show that seeds belonging to lineages 54 and 91 are more tolerant to high temperatures. The highest expression of $\alpha$-amylase is observed in maize seeds from lineages 30 and 91 following submission to controlled deterioration. Following controlled deterioration, the highest levels of gene expression do not correlate positively with the most tolerant materials.

Low expression of genes involved in heat-resistant protein systems were observed in lineage 44, which is more susceptible to high temperatures. The highest gene expression of LEA D-34, ZmAN13, and AOX-1 was observed in seeds from lineage 64, following submission to controlled deterioration.

\section{ACKNOWLEDGMENTS}

Research supported by Coordenação de Aperfeiçoamento de Pessoal de Nível Superior (CAPES) and Fundação de Amparo à Pesquisa do Estado de Minas Gerais (FAPEMIG).

\section{REFERENCES}

Abreu VA, Pinho EVR, Pinho RG, Nave GMF, et al. (2014). Physiological performance and expression of isozymes in maize seeds subjected to water stress. J. Seed Sci. 36: 40.

Alfenas AC (2006). Eletroforese de isoenzimas e proteínas afins: fundamentos e aplicações em plantas e microorganismos. UFV, Viçosa.

Allakhverdiev SI, Kreslavski VD, Klimov VV, Los DA, et al. (2008). Heat stress: an overview of molecular responses in photosynthesis. Photosynth. Res. 98: 541-550.

Andrade T, Von Pinho EV, Von Pinho RG, Oliveira GE, et al. (2013). Physiological quality and gene expression related to heatresistant proteins at different stages of development of maize seeds. Genet. Mol. Res. 12: 3630-3642. 
Baker J, Van Dennsteele C and Dure L 3rd (1988). Sequence and characterization of 6 Lea proteins and their genes from cotton. Plant Mol. Biol. 11: 277-291.

Basavarajappa BS, Shetty HS and Prakash HS (1991). Membrane deterioration and other biochemical changes, associated with accelerated aging of maize seeds. Seed Sci. Technol. 19: 279-286.

Blackman SA, Wettlaufer SH, Obendorf RL and Leopold AC (1991). Maturation proteins associated with desiccation tolerance in soybean. Plant Physiol. 96: 868-874.

Boucher V, Buitink J, Lin X, Boudet J, et al. (2010). MtPM25 is an atypical hydrophobic late embryogenesis-abundant protein that dissociates cold and desiccation-aggregated proteins. Plant Cell Environ. 33: 418-430.

BRASIL (2009). Ministério da Agricultura, Pecuária e Abastecimento. Regras para análise de sementes. Brasília.

Buchanan BB, Gruissem W and Jones RL (2005). Biochemistry and Molecular Biology of Plants. American Society of Plant Physiologists, Rockville.

Cargnin A, De Souza MA, Cunha DF, Dos Santos D, et al. (2006). Tolerância ao estresse de calor em genótipos de trigo na fase de germinaçãode trigo na fase de germinação. Bragantia, Campinas 65: 245-251.

De Simoni F, Costa RS, Fogaça CA and Gerolineto E (2011). Seeds of Sorghum bicolor L. - Gramineae, subject to water stress simulated with PEG (6000). Rev. Biol. Cienc. Terra 11: 188-192.

Delouche JC (2004). O problema nem sempre é a qualidade das sementes. Seed News 8: 42.

Ferreira DF (2000). Análises estatísticas por meio do SIVAR para Windows ${ }^{\circledR}$ Versão 4.0. In: Reunião Anual da Região Brasileira da Sociedade Internacional de Biometria, 45, São Carlos. Programas e Resumos, UFSCAR, São Carlos.

Franco OL, Rigden DJ, Melo FR and Grossi-De-Sá MF (2002). Plant -amylase inhibitors and their interaction with insect a-amylases. Eur. J. Biochem. 269: 397-412.

Gachon C and Saindrenan P (2004). Real-time PCR monitoring of fungal development in Arabidopsis thaliana infected by Alternaria brassicicola and Botrytis cinerea. Plant Physiol. Biochem. 42: 367-371.

Galau GA, Jakobsen KS and Hughes DW (1991). The controls of late dicot embryogenesis and early germination. Physiol. Plant. 81: 280-288.

Hampton JG, Johnstone KA and Eua-Umpon V (1992). Ageing vigour tests for mungbean and French bean seed lots. Seed Sci. Technol. 20: 643-653.

Iba K (2002). Acclimative response to temperature stress in higher plants: approaches of gene engineering for temperature tolerance. Annu. Rev Plant Biol. 53:225-245.

Jin Y, Wang M, Fu J, Xuan N, et al. (2007). Phylogenetic and expression analysis of ZnF-AN1 genes in plants. Genomics 90: 265-275.

Keunen E, Peshev D, Vangronsveld J, Van Den Ende W, et al. (2013). Plant sugars are crucial players in the oxidative challenge during abiotic stress: extending the traditional concept. Plant Cell Environ. 36: 1242-1255.

Marcos Filho, J (2005). Fisiologia de sementes de plantas cultivadas. Fealq, Piracicaba.

Miller G, Shulaev V and Mittler R (2008). Reactive oxygen signaling and abiotic stress. Physiol. Plant. 133: $481-489$.

Moore AL, Albury MS, Crichton PG and Affourtit C (2002). Function of the alternative oxidase: is it still a scavenger? Trends Plant Sci. 7: 478-481.

Nerson H (2007). Seed production and germinability of cucurbit crops. Seed Sci. Biotechnol. 1: 1-10.

Padilha L, et al. (2001). Relação entre o teste de deterioração controlada e o desempenho de sementes de milho em diferentes condições de estresse. Rev. Bras. 23: 198-204.

Peet MM and Willits DH (1998). The effect of night temperature on greenhouse grown tomato yields in warm climate. Agric. Forest Meteorol. 92: 191-202.

Sbrussi CAG and Zucareli C (2014). Germinação de sementes de milho com diferentes níveis de vigor em resposta à diferentes temperaturas. Semina Ciências Agrárias 35: 215-226.

Silva-Neta IC, Pinho EV, Veiga AD, Pìnho RG, et al. (2015). Expression of genes related to tolerance to low temperature for maize seed germination. Genet. Mol. Res. 14: 2674-2690.

Taiz L and Zeiger E (2004). Fisiologia Vegetal. 3. ed. Artmed, Porto Alegre.

Wang CT, Yang Q and Wang CT (2011). Isolation and functional characterization of ZmDBP2 encoding a dehydrationresponsive element-binding protein in Zea mays. Plant Mol. Biol. Report. 29: 60-68.

Wang YR, Hampton JG and Hill MJ (1991). Red clover vigour testing - Effects of three test variables. Seed Sci. Technol. 22: 99-105.

Xuan N, Jin H, Zhang $\mathrm{H}$, Xie $\mathrm{Y}$, et al. (2011). A putative maize zinc-finger protein gene, ZmAN13, participates in abiotic stress response. Plant Cell Tiss. Organ Cult. 107: 101-112.

Zhu JK (2002). Salt and drought stress signal transduction in plants. Ann. Rev. Plant Biol. 53: 247-273. 